\title{
GLOBAL ENVIRONMENTAL GOVERNANCE AS A REGULATORY AND \\ GUARANTEE CRITERION FOR ENVIRONMENTAL JUSTICE
}

GOVERNANÇA AMBIENTAL GLOBAL COMO CRITÉRIO REGULADOR E GARANTIDOR DA JUSTIÇA AMBIENTAL

GOBERNANZA AMBIENTAL GLOBAL COMO CRITERIO REGULADOR Y GARANTIZADOR DE LA JUSTICIA AMBIENTAL

\section{Denise Schmitt Siqueira Garcia ${ }^{1}$ Heloise Siqueira Garcia ${ }^{2}$ Andrés Molina Giménez ${ }^{3}$}

$1 \quad$ PhD from the University of Alicante, in Spain. Professor of the Stricto Sensu Postgraduate Program in Legal Science at UNIVALI - PPCJ, in the Doctoral and Master's in Legal Science courses, and in the Law Course at UNIVALI. Master in Environmental Law from the University of Alicante - Spain. Master in Legal Science from the UNIVALI. Specialist in Civil Procedural Law. Member of the research group "State, Environmental Law, Transnationality". Researcher of the research project approved at CNPq entitled "Comparative analysis of the limits and possibilities of strategic environmental assessment and its effectiveness in order to contribute to a better environmental management of port activity in Brazil and Spain." Lawyer. E-mail: denisegarcia@univali.br.

2 PhD student of the Stricto Sensu Postgraduate Program in Legal Science - PPCJ - UNIVALI. Researcher of Research Groups linked to CNPq "Prospective Law and Sustainability" and "Environmental Law, Transnationality and Sustainability". Professor in the Law Course at the AVANTIS college and SINERGIA college. Master in Legal Science at the PPC] - UNIVALI. Master in Environmental Law and Sustainability at the University of Alicante - Spain. Postgraduate in Social Security and Labor Law at UNIVALI. Graduated in Law at UNIVALI. Lawyer. Email: heloisegarcia@univali.br.

3 Professor of Administrative Law. University of Alicante. Secretary of Water and Environmental Sciences of the University of Alicante. Former Legal Adviser of the Sindic de Greuges of the Valencian Community (Regional Ombudsman). Visiting scholar at the Universities of Harvard, Pace Law School, and Padova. 
Abstract: This article deals with the theme of Global Environmental Governance for the achievement of Environmental Justice. Its general objective is to analyze the former, in its public, business and civil society spheres, for the regulation and guarantee of the latter. At the end, it makes the observation that Environmental Justice, as a common humanitarian problem, is the main objective of Global Environmental Governance. In the methodology, the inductive method was adopted, applying the techniques of referent, category, operational concepts, bibliographic research, and annotation.

Keywords: Environmental Governance; Global Governance; Environmental Justice.

Resumo: Este artigo trabalha com a temática da Governança Ambiental Global para o alcance da Justiça Ambiental, apresentando como objetivo geral analisar a importância da primeira em suas esferas pública, empresarial e da sociedade civil para a regulamentação e garantia da segunda. Constatando-se, ao final, que a Justiça Ambiental, na qualidade de problema comum humanitário, apresenta-se como o objetivo principal da Governança Ambiental Global. Na metodologia foi adotado o método indutivo, tendo sido acionadas as técnicas do referente, da categoria, dos conceitos operacionais, da pesquisa bibliográfica e do fichamento.

Palavras-Chave: Governança Ambiental; Governança Global; Justiça Ambiental.

Resumen: Este artículo trabaja con la temática de la Gobernanza Ambiental Global para el alcance de la Justicia Ambiental, presentando como objetivo general analizar la importancia de la primera en sus esferas publica, empresarial y de la sociedad civil para la regulación y garantía de la segunda. Se constató, al final del trabajo, que la Justicia Ambiental, como problema común humanitario, se presenta como el objetivo principal de la Gobernanza Ambiental Global. En la metodología fue adoptado el método inductivo, y fueron accionadas las técnicas del referente, de la categoría, de los conceptos operacionales, de la investigación bibliográfica y del fichaje.

Palabras Clave: Gobernanza Ambiental; Gobernanza Global; Justicia Ambiental. 


\section{INTRODUCTION}

his article aims to encourage debate on two themes of great importance: Governance and Environmental Justice. Governance, in

_L this context, should be seen as a process of interaction between social and institutional actors to achieve effective social/environmental management. This effective social/environmental management, in turn, will enable the achievement of Environmental Justice, which is the other central theme of this research.

Thus, the overall objective is to analyze the importance of Global Environmental Governance, considered in the public, business and civil society spheres, for the regulation and guarantee of Environmental Justice, considering it as a concept of justice in the distribution of the environment between people. Its specific objectives are to understand Global Governance, from the emergence of its theoretical construction and conceptual differentiation from government and governability; and to study Environmental Justice from historical and conceptual perspectives, but mainly from the perspective of Global Environmental Governance.

The research problem of this article can be summarized as follows: What is Global Governance and what is its importance for achieving Environmental Justice?

To achieve these objectives, the article was divided in three parts: Notions of Global Governance; distinction of nomenclatures: government and Governance; and Environmental Justice and Global Environmental Governance.

In terms of methodology, the authors selected the inductive method, with the techniques of referent, category, operational concepts, bibliographical research and annotation. ${ }^{4}$

\section{NOTIONS OF GLOBAL GOVERNANCE}

The first manifestations of environmental governance were prompted by the depletion of natural resources, such as wood for the construction of housing, 4 As established in the work of PASOLD, Cesar Luiz. Metodologia da pesquisa jurídica:

teoria e prática. 13. ed. Florianópolis: Conceito Editorial, 2015. p. 58. 
fortifications, furniture, instruments and fuel, a natural resource that had been intensely exploited since medieval times. ${ }^{5}$

Thus, at a global level, there were several cases of environmental damage that attracted the attention of the international community, prompting reflection on the need to protect the environment.

Some examples of these incidents are:

1. 10.6.1976. Seveso, Itália. Acidente industrial provocado por empresa Suíça. Tanques de armazenagem romperam, liberando TCDD $(2,3,7,8$ tetraclorodibenzo - $p$ - dioxina). Esse desastre levou a União Europeia a publicar a Diretiva de Seveso, que estabeleceu regulamentos rígidos, tendo sido atualizada em 1999 e complementada em 2005;

2. 1978. Acidente com o satélite artificial soviético de telecomunicações Cosmos 924, que caiu em território canadense, despejando material radioativo;

3. 16.3.1978. O superpetroleiro Amoco Cádiz, vindo do golfo Pérsico a Roterdã, com 227.000 toneladas de óleo cru, partiu-se ao meio na costa bretã, França, em uma tempestade, criando uma maré que destruiu praias e vida marinha, com enormes prejuízos à pesca e ao turismo;

4. 1984. Acidente na cidade de Bhopal, na Índia, envolvendo uma fábrica de pesticidas, cuja atividade negligente causou um vazamento de gás tóxico que envenenou toda a população, matando mais de 2.000 pessoas e deixando 2000.000 cegas ou feridas;

5. 1986. Acidente nuclear de Chernobyl, na Ucrânia, URSS, cuja explosão liberou uma nuvem de material radioativo que foi levada pelo vento aos países vizinhos;

6. 1986. Incêndio ocorrido na empresa química Sandoz, na Suíça. O rio Reno foi gravemente contaminado por produtos químicos agrícolas, solventes e mercúrio, matando a fauna aquática e ameaçando o abastecimento de água potável na Alemanha e da Holanda;

7. entre 1984 e 1987, 60 milhões de pessoas, na maioria crianças, morreram de doenças intestinais decorrentes de desnutrição e da ingestão de água imprópria para o consumo.

5 BARBIERI, José Carlos. Gestão ambiental empresarial. Conceitos, modelos e instrumentos. Ed. São Paulo, Saraiva, 2011, p. 20. 
8. entre 1984 e 1987, a crise africana ligada ao meio ambiente e ao desenvolvimento, desencadeada pela seca, pôs em risco de vida de 35 milhões de pessoas, matando cerca de um milhão. ${ }^{6}$

The need for global and effective Governance is undeniable. This has been the consensus since the beginning of the 21st century, with the expression Global Governance being used in meetings, documents and declarations of organizations such as the UN, G8 and G20, as an essential component of economic and social development, integration, and the resolution of common problems. ${ }^{7}$

"Problemas ambientais exigem respostas globais. As iniciativas para enfrentálos propiciam ao longo do tempo o surgimento de diversos acordos multilaterais, bem como órgãos intergovernamentais, para administrá-los, e mecanismos de ação internacional". ${ }^{\circ}$

Diversos congressos científicos internacionais antecederam as iniciativas de gestão ambiental de caráter global. A ideia de realizar um encontro internacional sobre proteção da natureza segue paralelamente à criação de parques nacionais nos Estados Unidos, iniciada pelo Parque de Yellowstone, em 1872. O primeiro acordo internacional foi assinado em Paris, em 1883, e seu objetivo era proteger as focas do mar de Behring. Esta cidade também foi sede da Convenção para Proteção dos Pássaros Úteis à Agricultura realizada em 1895 e do Congresso Internacional para proteção da paisagem. O I Congresso Internacional para proteção da natureza, realizado em Paris, em 1923, é considerado o início de um novo período na história da gestão ambiental global, quer por ter apresentado uma abordagem bastante completa sobre os problemas ambientais, quer pela luta para criar uma instituição internacional permanente para proteção da natureza. Porém, os problemas ambientais seriam apresentados na sua forma moderna somente no final da década de 1960 na ONU. Por forma moderna entende-se um tratamento global e integrado e não fragmentado como ocorrera até então. ${ }^{9}$

For the effectiveness of this environmental protection, the implementation of an international infrastructure for global environmental management was

6 GRANZIERA, Maria Luiza. Direito ambiental. Rio de Janeiro: Editora Atlas, 2009, p. 37-39.

7 GONÇALVES, Alcindo; COSTA, José Augusto Fontoura. Governança Global e Regimes Internacionais. São Paulo: Almedina, 2011, p. 15.

8 BARBIERI, José Carlos. Gestão ambiental empresarial. Conceitos, modelos e instrumentos. Ed. São Paulo, Saraiva, 2011, p. 27.

9 BARBIERI, José Carlos. Gestão ambiental empresarial. Conceitos, modelos e instrumentos. Ed. São Paulo, Saraiva, 2011, p. 28. 
started. It is important to create this infrastructure in order to increase the number of observatories to monitor and evaluate the state of the environment; and multilateral development banks (World Bank, Inter-American Development Bank, etc.), and for the creation of the United Nations Environment Program (UNEP), which would centralize a large part of the UN's environmental issues. ${ }^{10}$

Os recursos globais comuns, como a atmosfera e os oceanos fora das águas territoriais, inicialmente constituem recursos de livre acesso global, disponíveis para todos. Porém, quando as nações estabelecem acordos para limitar seu uso e evitar abusos, elas estão efetivamente transformando recursos globais de livre acesso em recursos globais de propriedade comum. É isso que procuram fazer os acordos intergovernamentais sobre meio ambiente, como os comentados anteriormente. Como os globais comuns são bens de todas as nações, nenhuma se sentirá na obrigação de cuidar deles sozinha. ${ }^{11}$

Thus, the term "governance" arises from reflections mainly led by the World Bank. The idea is that government capacity should not be evaluated solely based on the results of government policies, but also by the way in which the government exercises its power. ${ }^{12}$

Governance provides a way of solving common problems. Therefore, it is seen that it

[...] emergiu dos entendimentos restritos no Congresso de Viena que, em 1845, redesenhou o mapa da Europa depois da derrota da França Napoleônica, seguidos de outros eventos marcantes: fixação dos princípios do direito marítimo, em 1856, em Paris; partilha imperial na África e outras disposições colonialistas, em 1884, em Berlim; imposição de reparações à Alemanha e criação de Estados na Europa, 1910, em Versalhes; e a criação da ONU, na conferência de São Francisco, em 1945. ${ }^{13}$

In academic circles, Governance began to assume its own independent character in the 1980s, when the World Bank and the International Monetary

10 BARBIERI, José Carlos. Gestão ambiental empresarial. Conceitos, modelos e instrumentos. Ed. São Paulo, Saraiva, 2011, p. 29.

11 BARBIERI, José Carlos. Gestão ambiental empresarial. Conceitos, modelos e instrumentos. Ed. São Paulo, Saraiva, 2011, p. 59.

12 GONÇALVES, Alcindo. O conceito de Governança. In: Congresso Nacional do CONPEDI, XIV, Fortaleza, 2005. Anais do..., Florianópolis: Fundação Boiteux, 2006, p. 197-213.

13 GONÇALVES, Alcindo; COSTA, José Augusto Fontoura. Governança Global e Regimes Internacionais. São Paulo: Almedina, 2011, p. 16. 
Fund (IMF) began to use the term "good governance" as a guiding principle for the work and actions of their member states.

A expressão "Governança global começou a se legitimar entre cientistas e tomadores de decisões a partir do final da década de 1980, basicamente para designar atividades geradoras de instituições (regras do jogo) que garantem que um mundo formado por Estado-nação se governe sem que disponha de governo central. ${ }^{14}$

For these organisms, "good governance" should have eight elements: 1) participation; 2) rule of law; 3) transparency; 4) responsiveness; 5) consensus orientation; F) equity and inclusion; 7) effectiveness and efficiency; and 8) accountability. ${ }^{15}$ These criteria are listed in the UNDP Governance for Sustainable Human Development report of 1997, which also adds the item "strategic vision".

In 2002, the UNDP Economic Development Report also developed the concept of democratic governance,

[...] defendia que as liberdades civis e políticas, bem como a participação, têm valor fundamental como fim ao desenvolvimento em si mesmo. Assim, na essência, Governança democrática significa, além das instituições eficientes e ambiente previsível ao desenvolvimento econômico e político para o crescimento econômico e efetivo funcionamento dos serviços públicos, liberdades fundamentais, respeito aos direitos humanos, remoção da discriminação de raça, gênero e grupo ético, necessidades das futuras gerações quanto a políticas de desenvolvimento. ${ }^{16}$

The current phase of Global Environmental Governance is characterized by the implementation and deepening of multilateral agreements, which involves national states, local governments, companies and other actors putting their provisions and recommendations into practice.

Therefore, some examples of global environmental governance are highlighted:

14 VEIGA, José Eli. A desgovernança mundial da sustentabilidade. São Paulo: Editora 34, 2013, p. 13.

15 GONÇALVES, Alcindo; COSTA, José Augusto Fontoura. Governança Global e Regimes Internacionais. São Paulo: Almedina, 2011, p. 31.

16 GONÇALVES, Alcindo; COSTA, José Augusto Fontoura. Governança Global e Regimes Internacionais. São Paulo: Almedina, 2011, p. 31. 
a) Convenção sobre mudanças climáticas devido o aquecimento global e a destruição da camada de ozônio;

b) Convenção da Biodiversidade, a qual foi aprovada na CNUMAD em 1992 e em janeiro de 2011 já contava com a adesão de 193 países, dentre eles o Brasil, tendo como finalidade a conservação da diversidade biológica, o uso sustentável dos seus componentes e a justa e equitativa distribuição dos benefícios obtidos da utilização dos recursos genéticos, incluindo o acesso apropriado a esses recursos e a apropriada transferência de tecnologia;

c) A Convenção sobre o Comércio Internacional das Espécies da Fauna e Flora Selvagens em Perigo de Extinção (CITES), criada em 1973, tendo como objetivo controlar e limitar o comércio das espécies ameaçadas de extinção listadas em três anexos. ${ }^{17}$

Within the view that the Environment cannot be dealt with in a cross-border way, there is a need for global discussions and regulations of Governments, such as those previously endorsed.

\section{DISTINCTION OF NOMENCLATURES: GOVERNANCE}

AND GOVERNMENT

In order to fully understand the word Governance, it is necessary to discriminate between it, and other close terms, such as government, Governance and governability.

Government refers to activities supported by a formal authority and by the police power, which enforce the policies instituted. This represents "o conjunto de pessoas que exercem o poder político e que determinam a orientação política de uma determinada sociedade. É preciso, porém acrescentar que o poder de governo, sendo habitualmente institucionalizado, está normalmente associado à noção de Estado"18.

17 BARBIERI, José Carlos. Gestão ambiental empresarial. Conceitos, modelos e instrumentos. Ed. São Paulo, Saraiva, 2011, p. 31-50.

18 GONÇALVES, Alcindo; COSTA, José Augusto Fontoura. Governança Global e Regimes Internacionais. São Paulo: Almedina, 2011, p. 42. 
Governability refers to the state dimension of the exercise of power. "Diz respeito às condições sistêmicas e institucionais sob as quais se dá o exercício do poder, tais como as características do sistema político, a forma de governo, as relações entre os Poderes, o sistema de intermediação de interesses". ${ }^{19}$ It is directly linked to the state and represents a set of attributes essential to the exercise of government, without which no power will be exercised.

Governance is not restricted to the managerial and administrative aspects of the State. It exists through articulation and cooperation between social and political actors and institutional arrangements that coordinate and regulate transactions within and across the borders of the economic system. ${ }^{20}$ It can then be exercised by political parties, non-governmental organizations, informal social networks, and associations, i.e. Governance encompasses society as a whole. In this sense, they propose that, "em nível transnacional, os atores não estatais, principalmente as ONG's, assumam lugar central no espaço público mundial, levando novas demandas sociais e novas instâncias de regulação sistêmica" ${ }^{21}$

Governance is not the same government, since it requires a formal authority with police power, it is a broader phenomenon than government, which encompasses non-governmental institutions as well as non-governmental institutions.

[...] governo implica em atividades apoiadas por uma autoridade formal e poderes coercitivos; já na Governança, os objetivos são atingidos não necessariamente através de uma autoridade formal que os impõem a seus membros, mas através de metas comuns e compartilhadas por todos que fazem parte do sistema. A Governança é, portanto, mais abrangente do que o governo e por isso seus objetivos e as formas de atingi-los acabam por ser mais duradouros. ${ }^{22}$

19 GONÇALVES, Alcindo. O conceito de Governança. In: Congresso Nacional do CONPEDI, XIV, Fortaleza, 2005. Anais do..., Florianópolis: Fundação Boiteux, 2006, p. 197-213.

20 GONÇALVES, Alcindo. O conceito de Governança. In: Congresso Nacional do CONPEDI, XIV, Fortaleza, 2005. Anais do..., Florianópolis: Fundação Boiteux, 2006, p. 197-213.

21 LORENZETTI, Julia Vaz; CARRION, Rosinha Machado. Governança ambiental global: atores e cenários. Cadernos EBAPE BR, v. 10, n. 03, opinião 2. Rio de Janeiro, set. 2012, p. 723.

22 ARAÚJO, Izabela Viana. A Governança global e a atuação das redes internacionais de cidades. In. Encontro Nacional ABRI, 3, PUC Minas, 2011. Anais. Available at http://www. proceedings.scielo.br/scielo.php?pid=MSC0000000122011000200031\&script=sci_arttext. Consulted on August 3, 2016. 
Alcindo Gonçalves ${ }^{23}$ defines Governance as the "[...] meio e processo capaz de produzir resultados eficazes, sem necessariamente a utilização expressa da coerção. Mas a Governança não exclui a dimensão estatal: ao contrário, acaba por envolvê-la".

A report prepared by the Commission on Global Governance defines Governance as "a totalidade das diversas maneiras pelas quais os indivíduos e as instituições, públicas e privadas, administram seus problemas comuns. É um processo contínuo pelo qual é possível acomodar interesses conflitantes ou diferentes e realizar ações cooperativas". ${ }^{24}$

Thus, governance should be seen as a democratic system of laws and social institutions, and its progress depends on regulation, established by some mechanism of democratic consensus and translated into normative instruments capable of ensuring harmony, peace and progress.

Governance ceases to be an attribute of any government and becomes, in an increasingly deeper way, an instrument for increasing cohesion among national, regional and global entities and organizations.

The State continues to be of vital importance, as the "imperativos da constituição de um sistema de Governança mundial não devem se sobrepor às prerrogativas do Estado, destacando ainda os riscos que isso implica para consolidação do processo democrático, em particular, para os países periféricos". ${ }^{25}$

El concepto de gobernanza en un contexto de globalización se ha ido desarrollando en la últimas tres décadas y ha cobrado relevancia desde 1190 convirtiéndose en un concepto clave en el debate político. Está relacionado con el ámbito de la toma de decisiones y con el arte de manejar las sociedades y organizaciones, influido en gran medida con el ascendo de la nueva gestión pública y el cambio de paradigma en la administración pública. ${ }^{26}$

23 GONÇALVES, Alcindo. O conceito de Governança. In: Congresso Nacional do CONPEDI, XIV, Fortaleza, 2005. Anais do..., Florianópolis: Fundação Boiteux, 2006, p. 197-213.

24 COMISSÃO SOBRE GOVERNANÇA GLOBAL. Nossa comunidade global. O relatório da comissão sobre Governança Global. Rio de Janeiro: Editora FGV, 1996, p. 02.

25 LORENZETTI, Julia Vaz; CARRION, Rosinha Machado. Governança ambiental global: atores e cenários. Cadernos EBAPE BR, v. 10, n. 03, opinião 2. Rio de Janeiro, set. 2012, p. 723.

26 MONTIEL, Luis Enrique Concepción. Governanza y democracia em América Latina en un contexto de globalización. In. MONTIEL Luis Concepción; HERNANDÉZ, Patricia Moctezuma 
It should be noted that Governance is not a legal concept, but relates more to Political Science and International Relations. However, since Law is an applied social science, it is important to understand and verify the applicability of the concept to its practical theory. ${ }^{27}$

No direito interno a Governança surge como a busca de alternativas fora do plano estrito do Estado, mas é evidente que no nível doméstico a importância e relevância dos temas e ações estatais é muito mais presente. Enquanto isso, o Direito Internacional tem muito mais pontos em comum com a Governança. Como já mencionado acima, o processo de globalização tem levado à redefinição do conceito de soberania, com a emergência crescente de ONG's e empresas multi e transnacionais, significando a crescente passagem para o plano da Governança global. ${ }^{28}$

New problems of cross-border dimensions will reinforce the trend towards Governance. e.g. environmental pollution, international migration, and even the globalization of markets and the internationalization of corporations. All this movement led to the limitation of the competence, mandate and authority of the national States. ${ }^{29}$ It is believed that in the future, there will be more and more Governance and less government.

\section{ENVIRONMENTAL JUSTICE AND GLOBAL ENVIRONMENTAL GOVERNANCE}

Concepts suchas Environmental Justice have increasingly been incorporated into classic environmental doctrine, based on the observed disparity in environmental relations between people from different regions or disparate economic capacities. The idea of Environmental Justice arises, then, as the concept of justice in the distribution of the environment among people.

(org). Governanza global y democracia. Mexicali, Baja California: Universidad Autônoma de Baja California, 2010, p. 302.

27 GONÇALVES, Alcindo. O conceito de Governança. In: Congresso Nacional do CONPEDI, XIV, Fortaleza, 2005. Anais do..., Florianópolis: Fundação Boiteux, 2006, p. 197-213.

28 GONÇALVES, Alcindo. O conceito de Governança. In: Congresso Nacional do CONPEDI, XIV, Fortaleza, 2005. Anais do..., Florianópolis: Fundação Boiteux, 2006, p. 197-213.

29 GONÇALVES, Alcindo; COSTA, José Augusto Fontoura. Governança Global e Regimes Internacionais. São Paulo: Almedina, 2011, p. 35. 
As Carvalho ${ }^{30}$ teaches, Environmental Justice, which she sees as synonymous with social justice, "[...] baseia-se na noção de que a dimensão dos recursos naturais e a desestabilização dos ecossistemas podem atingir de modo desigual e injusto, determinadas pessoas ou grupos de indivíduos." On that basis, it exists to constitute a new expectation that integrates social and environmental struggles and movements, going beyond conflicts for ecological distribution of the natural resources.

Acselrad ${ }^{31}$ points out that the investigation of the discussionaboutEnvironmental Justice is based primarily on the argument that neither the defenders of ecological modernization, nor the Risk Society theorists succeeded in incorporating social diversity into the construction of risk, nor into the presence of a political logic that would guide the unequal distribution of environmental damages. It was in this context that the movements for Environmental Justice emerged.

Carvalho $^{32}$ further reiterates that the logic is the articulation between environmental degradation and social injustice, yet the ecological and "[...] a sociedade de risco não vinculam a diversidade social na construção do risco e a política para orientar a distribuição desigual dos danos ambientais."

According to Acselrad ${ }^{33}$ (2002, p.760), the Environmental Justice movement would began in the United States in the 1980s, starting with a creative articulation between social, territorial, environmental and civil rights struggles.

As stated at the beginning of this article, discussions on Governance also emerged in academic circles, through the attitudes of the World Bank and the International Monetary Fund (IMF), which established requirements for the

30 CARVALHO, Sônia Aparecida de. Justiça Social e Ambiental: um instrumento de consolidação à sustentabilidade. Revista Eletrônica Direito e Política. Itajaí, v. 9, n. 2, p. 755779, 20 quadrimestre de 2014, p. 776.

31 ACSELRAD, Henri. Justiça Ambiental e Construção Social do Risco. In: Encontro da Associação Brasileira de Estudos Populacionais, XIII, 2002. Outro Preto - MG. Anais... Available at: <http://www.abep.nepo.unicamp.br/docs/anais/pdf/2002/GT_MA_ST5_Acselrad_texto.pdf>. Accessed on: July 26, 2016, p. 4.

32 CARVALHO, Sônia Aparecida de. Justiça Social e Ambiental: um instrumento de consolidação à sustentabilidade. Revista Eletrônica Direito e Política. Itajaí, v. 9, n. 2, p. 755779, 20 quadrimestre de 2014, p. 760.

33 ACSELRAD, Henri. Justiça Ambiental e Construção Social do Risco. In: Encontro da Associação Brasileira de Estudos Populacionais, XIII, 2002. Outro Preto - MG. Anais... Available at: <http://www.abep.nepo.unicamp.br/docs/anais/pdf/2002/GT_MA_ST5_Acselrad_texto.pdf>. Accessed on: July 26 2016, p. 760. 
achievement of "good governance". Within these criteria of "good governance" is the need for "equity and inclusion", precisely what Environmental Justice seeks.

At the end of the 1960s, there was a redefinition of the series of attacks against inadequate sanitation, chemical contamination of housing and workplaces, and improper disposal of hazardous and toxic waste, triggering the notion of geographical equity. ${ }^{34}$

In the 1970s, "[...] sindicatos preocupados com saúde ocupacional, grupos ambientalistas e organizações de minorias étnicas articularam-se para elaborar em suas pautas respectivas o que entendiam por 'questões ambientais urbanas'."35 Several studies have already pointed to a spatially unequal distribution of pollution by race, among populations most exposed to it.

The movement was consolidated following the struggles over the creation of the Warren County PCB landfill for the dumping of contaminated soil, in Afton, Warren county, North Carolina, in 1982. "A partir de lutas de base contra iniquidades ambientais a nível local, similares à de Afton, o movimento elevou a 'Justiça Ambiental' à condição de questão central na luta pelos direitos civis." ${ }^{16}$ Almost simultaneously, the movement induced the incorporation of environmental inequality into the agenda of the traditional environmental movement.

From 1987 onwards, various organizations began to discuss the links between race, poverty and pollution more intensely, and researchers began to study the links between environmental problems and social inequality, and even attempted to elaborate the instruments of an "Equity Environmental Assessment" that incorporated social variables into traditional impact assessment studies. ${ }^{37}$

34 ACSELRAD, Henri. Justiça Ambiental e Construção Social do Risco. In: Encontro da Associação Brasileira de Estudos Populacionais, XIII, 2002. Outro Preto - MG. Anais... Available at: <http://www.abep.nepo.unicamp.br/docs/anais/pdf/2002/GT_MA_ST5_Acselrad_texto.pdf>. Accessed on: July 26 2016, p. 760.

35 ACSELRAD, Henri. Justiça Ambiental e Construção Social do Risco. In: Encontro da Associação Brasileira de Estudos Populacionais, XIII, 2002. Outro Preto - MG. Anais... Available at: <http://www.abep.nepo.unicamp.br/docs/anais/pdf/2002/GT_MA_ST5_Acselrad_texto.pdf>. Accessed on: July 26 2016, p. 06.

36 ACSELRAD, Henri. Justiça Ambiental e Construção Social do Risco. In: Encontro da Assoiação Brasileira de Estudos Populacionais, XIII, 2002. Outro Preto - MG. Anais... Available at: <http://www.abep.nepo.unicamp.br/docs/anais/pdf/2002/GT_MA_ST5_Acselrad_texto.pdf>. Accessed on: July 26 2016, p. 06.

37 ACSELRAD, Henri. Justiça Ambiental e Construção Social do Risco. In: Encontro da Associação Brasileira de Estudos Populacionais, XIII, 2002. Outro Preto - MG. Anais... Available 
But the real changes came in 1990, when the implications of these studies began to show results at state level, when the US Environmental Protection Agency set up a working group to study environmental risk in low-income communities. ${ }^{38}$

Then, in 1991, the "17 Principles of Environmental Justice" were approved at the First National People of Color Environmental Leadership Summit.

[...] estabelecendo uma agenda nacional para redesenhar a política ambiental dos EUA de modo a incorporar a pauta das 'minorias', comunidades ameríndias, latinas, afroamericanas e asiaticoamericanas, tentando mudar o eixo de gravidade da atividade ambientalista nos EUA. ${ }^{39}$

It was from this moment that the Environmental Justice movement became consolidated as a multicultural and multiracial network, initially in a national north American context, and later at an international level.

The theme was also the focus of an international event held in Niterói, Rio de Janeiro in 2001, the International Colloquium on Environmental Justice, Labor and Citizenship, an event that was consolidated in the Declaration of Principles of the Brazilian Environmental Justice Network, defining it based on a set of principles and practices:

a - asseguram que nenhum grupo social, seja ele étnico, racial ou de classe, suporte uma parcela desproporcional das conseqüências ambientais negativas de operações econômicas, de decisões políticas e de programas federais, estaduais, locais, assim como da ausência ou omissão de tais políticas;

b - asseguram acesso justo e eqüitativo, direto e indireto, aos recursos ambientais do país;

at: <http://www.abep.nepo.unicamp.br/docs/anais/pdf/2002/GT_MA_ST5_Acselrad_texto.pdf >. Accessed on: July 26, 2016, p. 08.

38 ACSELRAD, Henri. Justiça Ambiental e Construção Social do Risco. In: Encontro da Associação Brasileira de Estudos Populacionais, XIII, 2002. Outro Preto - MG. Anais... Available at: <http://www.abep.nepo.unicamp.br/docs/anais/pdf/2002/GT_MA_ST5_Acselrad_texto.pdf>. Accessed on: July 26, 2016, p. 08.

39 ACSELRAD, Henri. Justiça Ambiental e Construção Social do Risco. In: Encontro da Associação Brasileira de Estudos Populacionais, XIII, 2002. Outro Preto - MG. Anais... Available at: <http://www.abep.nepo.unicamp.br/docs/anais/pdf/2002/GT_MA_ST5_Acselrad_texto.pdf>. Accessed on: July 26, 2016, p. 08. 
c - asseguram amplo acesso às informações relevantes sobre o uso dos recursos ambientais e a destinação de rejeitos e localização de fontes de riscos ambientais, bem como processos democráticos e participativos na definição de políticas, planos, programas e projetos que lhes dizem respeito;

d - favorecem a constituição de sujeitos coletivos de direitos, movimentos sociais e organizações populares para serem protagonistas na construção de modelos alternativos de desenvolvimento, que assegurem a democratização do acesso aos recursos ambientais e a sustentabilidade do seu uso. ${ }^{40}$

It was also at that time, in 2002, that the UNDP presented the concept of "Democratic Governance" in a report on economic development, which emphasizes that in addition to efficient institutions and a predictable environment for economic and political development for economic growth, it is necessary for the effective functioning of public services, fundamental freedoms, respect for human rights, and removal of discrimination on grounds of race, gender and ethical group, which is precisely the objective that we hope to achieve with Environmental Justice.

It is interesting to note that this idea of Environmental Justice, or social justice, although almost a neologism, given that its appearance occurred in the mid-1990s as stated above, can be said to have roots in far deeper senses. The Roman Cicero, in his work "On the Duties"41, already sensed, in providing a letter of compassion for his son, that honesty, in the character of human duty, has four elements: 1) wisdom and prevention, which belong to the discovery of truth (the most natural of man); 2) acquisition and conservation of everything that is essential to life; 3 ) harmony of human society; 4) the greatness of the soul that stands out most by neglecting the goods and honors that are desired for themselves and for others.

Referring to the third element in particular, Cicero ${ }^{42}$ points out that its solidification takes place through the union between men, dividing itself into two parts: 1) justice, which is the first quality of the good man and implies to

40 BRASIL. Ministério do Meio Ambiente. Manifesto de Lançamento da Rede Brasileira de Justiça Ambiental. Disponível em: <http://www.mma.gov.br/destaques/item/8077>. Acesso em: 26 de jul. de 2016.

41 CÍCERO. Dos deveres. São Paulo: Martin Claret, 2002, p. 35-37.

42 CÍCERO. Dos deveres. São Paulo: Martin Claret, 2002, p. 37. 
do no harm to anyone, unless one has to rebut an insult, as well as to employ in common the goods of communion and to treat as their own only those who belong to us; and 2) charity, also called goodness or generosity. That is, justice itself allied with solidarity, which at that time, was understood only as charity.

From all this context out of which the notion of Environmental Justice emerges, Carvalho ${ }^{43}$ points out that it arises "[...] a partir do momento em que a dimensão dos recursos naturais e a desestabilização dos ecossistemas podem afetar, de modo desigual e injusto, determinados grupos sociais, em certas áreas geográficas."

According to Vieira ${ }^{44}$, his concept presents itself as a new conception in the approach to the environmental question, and is aimed at the combination of environmental and technical factors. Knowledge, popular practices and cultural constructions of their environment are recognized as determining factors in the legal treatment of conflicts affecting social and environmental goods. It is a true source of renewal of Environmental Law for a Sustainability Law.

From this perspective, Environmental Justice can be conceived as the "[...] distribuiçãoequitativa deriscos, custosebenefíciosambientais, independentemente de fatores não justificáveis racionalmente, tais como etnia, renda, posição social e poder; o igual acesso aos recursos ambientais e aos processos decisórios de caráter ambiental, traduzindo-se em sua democratização." ${ }^{45}$

Leff" defines it as "[...] um conjunto de direitos que problematiza todo o sistema jurídico, tanto sua racionalidade formal como seus princípios axiológicos e seus instrumentos normativos".

43 CARVALHO, Sônia Aparecida de. Justiça Social e Ambiental: um instrumento de consolidação à sustentabilidade. Revista Eletrônica Direito e Política. Itajaí, v. 9, n. 2, p. 755779, 20 quadrimestre de 2014, p. 763.

44 VIEIRA, Ricardo Stanziola. Justiça Ambiental e a Violação dos Direitos Humanos Socioambientais: desafios da sustentabilidade na era do desenvolvimentismo. In: CRUZ, Paulo Márcio; OLIVIERO, Maurizio; BRANDÃO, Paulo de Tarso. O Direito Contemporâneo e diálogos científicos UNIVALI e Perugia - Edição Comemorativa 10 anos do Convênio de Dupla Titulação entre a UNIVALI e a UNIPG. Perugia: UNIPG, 2016, p. 256.

45 VIEIRA, Ricardo Stanziola. Justiça Ambiental e a Violação dos Direitos Humanos Socioambientais: desafios da sustentabilidade na era do desenvolvimentismo. In: CRUZ, Paulo Márcio; OLIVIERO, Maurizio; BRANDÃO, Paulo de Tarso. O Direito Contemporâneo e diálogos científicos UNIVALI e Perugia - Edição Comemorativa 10 anos do Convênio de Dupla Titulação entre a UNIVALI e a UNIPG. Perugia: UNIPG, 2016, p. 257.

46 LEFF, Enrique. Saber ambiental: sustentabilidade, racionalidade, complexidade, poder. Tradução de Lúcia Mathilde Endlich Orth. 8. ed. Petrópolis: Vozes, 2011, p. 365. 
Moreover, in the words of Selene Herculano47, Environmental Justice can be understood as

[...] o conjunto de princípios que asseguram que nenhum grupo de pessoas, sejam grupos étnicos, raciais ou de classe, suporte uma parcela desproporcional das conseqüências ambientais negativas de operações econômicas, de políticas e programas federais, estaduais e locais, bem como resultantes da ausência ou omissão de tais políticas.

Complementarily in its dichotomy, Environmental Injustice could be understood as "[...] o mecanismo pelo qual sociedades desiguais destinam a maior carga dos danos ambientais do desenvolvimento a grupos sociais de trabalhadores, populações de baixa renda, grupos raciais discriminados, populações marginalizadas e mais vulneráveis." The Environmental Injustices "[...] são as implicações das opressões de classe, raça e gênero." ${ }^{48}$

Based on these considerations, it is observed that the development of the study of Environmental Justice, with the consequent strengthening of access to justice and of Environmental Governance, can help overcome the omissions and inefficiencies of the Public Power with respect to the control of degrading activities, as well as implementing and implementing environmental public policy and action programs. ${ }^{49}$

For merely didactic purposes, it should be pointed out that in contrast to this idea of Environmental Justice, Bosselmann ${ }^{50}$ presents the idea of Ecological Justice, understood as "[...] justiça da distribuição do ambiente entre as pessoas e a justiça das relações entre os seres humanos e o resto do mundo natural." ${ }^{51}$

47 HERCULANO, Selene. O clamor por Justiça Ambiental e contra o racismo ambiental. InterfacEHS, Revista de Gestão Integrada em Saúde do Trabalho e Meio Ambiente, São Paulo, v. 3, n. 1, artigo 2, Jan/April 2008, p. 02.

48 CARVALHO, Sônia Aparecida de. Justiça Social e Ambiental: um instrumento de consolidação à sustentabilidade. Revista Eletrônica Direito e Política. Itajaí, v. 9, n. 2, p. 755779, $2^{\circ}$ quadrimestre de 2014, p. 761.

49 VIEIRA, Ricardo Stanziola. Justiça Ambiental e a Violação dos Direitos Humanos Socioambientais: desafios da sustentabilidade na era do desenvolvimentismo. In: CRUZ, Paulo Márcio; OLIVIERO, Maurizio; BRANDÃO, Paulo de Tarso. O Direito Contemporâneo e diálogos científicos UNIVALI e Perugia - Edição Comemorativa 10 anos do Convênio de Dupla Titulação entre a UNIVALI e a UNIPG. Perugia: UNIPG, 2016

50 BOSSELMANN, Klaus. O princípio da sustentabilidade: transformando direito e Governança, 2015.

51 BOSSELMANN, Klaus. O princípio da sustentabilidade: transformando direito e Governança, 2015, p. 108. 
Affirming that the idea of Environmental Justice would not present the real and necessary consideration of the world, so that the dictates presented by it are based on the liberal concepts of justice and the anthropocentric discourse of ethics, which will not prove sufficient in the course of history, and should focus on ecological conceptions of justice and the ecocentric discourse of ethics.

A preocupação da ética ecológica é levar o mundo não humano para a comunidade da justiça para que não seja necessário confiar inteiramente em maiorias democráticas para a proteção ambiental. Ao fazer isso, todos têm o cuidado de observar que o reconhecimento do valor moral do mundo natural não indica equivalência moral com a humanidade. ${ }^{52}$ (BOSSELMANN, 2015, p. 114)

Two general principles of ecological justice are postulated: 1 . Ecological justice means that every natural person has the right to enjoy the fullness of his or her own way of life; and 2. All forms of life are mutually dependent and dependent on non-living forms. ${ }^{53}$

Briefly, the idea of Ecological Justice would include not only humans but also "nonhumans" in the justice community. It would include intragenerational, intergenerational and also interspecies justice. However, new models of governance would be necessary, since the current system would be incapable of conducting ecological justice in the doctrinally proposed way.

The truth is that regardless of the consideration of justice as environmental or ecological, or even social, it is an inseparable factor of both sustainability and solidarity. It is the result of the best equation of Solidarity Sustainability or Sustainable Solidarity, also being the central objective of Environmental Governance.

This is because the central objective of effective environmental governance is based on equity and inclusiveness, guaranteeing fundamental freedoms, respect for human rights, removal of race, gender and ethnic group discrimination and the need of future generations for development policies; precisely what is sought in Environmental Justice.

52 BOSSELMANN, Klaus. O princípio da sustentabilidade: transformando direito e Governança, 2015, p. 114.

53 BOSSELMANN, Klaus. O princípio da sustentabilidade: transformando direito e Governança, 2015, p. 144. 
The reality that is demonstrated, and that was built from the theoretical contribution of this work, is that the real scope of Environmental Justice depends on a Governance that is effective with the articulation and cooperation between the social actors, politicians and institutional arrangements that coordinate transactions within and across the boundaries of the economic system.

As sought to make clear in this essay, Environmental Justice depends on Governance-forming criteria, its scope also concerns the recognition of humanity as a single group, dependent on correlation, subject to the common problems that need to be managed.

Among the common humanitarian problems, poor distribution of environmental factors - both positive and negative - is the root cause of several other problems, and requires special attention. This is the approach that is sought through Environmental Justice. However, the management of such problems should follow Governance considerations and determinations, as stated in the first two items of this article, including strength, also to the nongovernmental organizations (NGOs), which are the main promoters of these Environmental Justice discourses and play an increasingly central role in the global public space.

FINAL CONSIDERATIONS

There have been several cases of global environmental damage that have drawn the attention of the international community to the need for further reflection on the need to protect the environment. To this end, discussions have begun on the need for a Governance that is Global and effective, and essential in the processes of economic and social development, integration and solving common problems.

Thus, it must be said that the Environment cannot be treated in a cross-border way, and there is a need for global discussions and Government regulations, to resolve common problems based on the recognition of humanity as a single group, dependent of correlation. 
Increasingly, concepts such as Environmental Justice have been constructed by observing the disparity in environmental relations between people from different regions or disparate economic capacities. Thus, it appears as a concept of justice in the distribution of the environment among people. Its reason for existing is to constitute a new expectation that integrates social and environmental struggles and movements beyond the conflicts of ecological distribution of natural resources.

The Environmental Justice movement began in the United States in the 1980s, based on a creative articulation between social, territorial, environmental and civil rights struggles. One of the main reasons for its emergence was the strength of the social organizations movements, mainly led by non-governmental organizations (NGOs), which continue to be the main promoters of these Environmental Justice discourses, and are increasingly playing a central role in the world public space.

During the history of this movement, it was only after the 1990s that Environmental Justice became consolidated as a multicultural and multiracial network, initially in a national context in the United States, and later at an international level, focused on combating a large common problem: poor distribution of environmental factors - both positive and negative -, which also generates several other common problems, as mentioned above, and which are focus of Global Environmental Governance, which should take care of its management.

The reality obtained from this theoretical construction is that the Environmental Justice is precisely the central objective of an effective Environmental Governance, based on equity and inclusion of all, in the guarantee of fundamental freedoms, with respect to Human rights, removal of race, gender and ethnic group discrimination and the need for development policies that will benefit future generations.

\section{BIBLIOGRAPHIC REFERENCES}

ACSELRAD, Henri. Justiça Ambiental e Construção Social do Risco. In: Encontro da Associação Brasileira de Estudos Populacionais, XIII, 2002. Outro Preto - MG. Anais. Available at: 
<http://www.abep.nepo.unicamp.br/docs/anais/pdf/2002/GT_MA_ST5_Acselrad_texto.pdf>. Consulted on July 26, 2016.

ARAÚJO, Izabela Viana. A Governança global e a atuação das redes internacionais de cidades. In. Encontro Nacional ABRI, 3, PUC Minas, 2011. Anais. Available at http://www.proceedings. scielo.br/scielo.php?pid=MSC0000000122011000200031\&script=sci_arttext. Consulted on August 3, 2016.

BARBIERI, José Carlos. Gestão ambiental empresarial. Conceitos, modelos e instrumentos. Ed. São Paulo, Saraiva, 2011.

BOSSELMANN, Klaus. O princípio da sustentabilidade: transformando direito e Governança, 2015.

BRASIL. Ministério do Meio Ambiente. Manifesto de Lançamento da Rede Brasileira de Justiça Ambiental. Available on: <http://www.mma.gov.br/destaques/item/8077>. Consulted on July 26, 2016.

CARVALHO, Sônia Aparecida de. Justiça Social e Ambiental: um instrumento de consolidação à sustentabilidade. Revista Eletrônica Direito e Política. Itajaí, v. 9, n. 2, p. 755-779, $2^{\circ}$ quadrimestre de 2014.

CÍCERO. Dos deveres. São Paulo: Martin Claret, 2002.

COMISSÃO SOBRE GOVERNANÇA GLOBAL. Nossa comunidade global. O relatório da comissão sobre Governança Global. Rio de Janeiro: Editora FGV, 1996.

GONÇALVES, Alcindo. O conceito de Governança. In: Congresso Nacional do CONPEDI, XIV, Fortaleza, 2005. Anais do..., Florianópolis: Fundação Boiteux, 2006, p. 197-213.

GONÇALVES, Alcindo; COSTA, José Augusto Fontoura. Governança Global e Regimes Internacionais. São Paulo: Almedina, 2011.

GRANZIERA, Maria Luiza. Direito ambiental. Rio de Janeiro: Editora Atlas, 2009.

HERCULANO, Selene. O clamor por Justiça Ambiental e contra o racismo ambiental. InterfacEHS, Revista de Gestão Integrada em Saúde do Trabalho e Meio Ambiente, São Paulo, v. 3, n. 1, artigo 2, Jan/Apr 2008. 
LEFF, Enrique. Saber ambiental: sustentabilidade, racionalidade, complexidade, poder. Tradução de Lúcia Mathilde Endlich Orth. 8. ed. Petrópolis: Vozes, 2011.

LORENZETTI, Julia Vaz; CARRION, Rosinha Machado. Governança ambiental global: atores e cenários. Cadernos EBAPE BR, v. 10, n. 03, opinião 2. Rio de Janeiro, Sep. 2012.

MONTIEL, Luis Enrique Concepción. Governanza y democracia em América Latina en un contexto de globalización. In. MONTIEL Luis Concepción; HERNANDÉZ, Patricia Moctezuma (org). Governanza global y democracia. Mexicali, Baja California: Universidad Autônoma de Baja California, 2010.

PASOLD, Cesar Luis. Prática da Pesquisa Jurídica e metodologia da pesquisa jurídica. Florianópolis: OAB/SC Editora, 2007.

VEIGA, José Eli. A desgovernança mundial da sustentabilidade. São Paulo: Editora 34, 2013.

VIEIRA, Ricardo Stanziola. Justiça Ambiental e a Violação dos Direitos Humanos Socioambientais: desafios da sustentabilidade na era do desenvolvimentismo. In: CRUZ, Paulo Márcio; OLIVIERO, Maurizio; BRANDÃO, Paulo de Tarso. O Direito Contemporâneo e diálogos científicos UNIVALI e Perugia - Edição Comemorativa 10 anos do Convênio de Dupla Titulação entre a UNIVALI e a UNIPG. Perugia: UNIPG, 2016.

Recebido em: setembro/2017

Aprovado em: dezembro/2017 